\title{
Hal-Hal Yang Perlu Diperhatikan Oleh Notaris Dalam Membuat Akta Perjanjian Notariil
}

\author{
Yogi Hanapiah", Sigit Prihanto**, Sri Endah Wahyuningsih ${ }^{* * *}$ \\ * Mahasiswa Program Magister (S2) Kenotariatan Fakultas Hukum UNISSULA, Semarang email : \\ HansWSL80@gmail.com \\ ** Mahasiswa Program Magister (S2) Ilmu Hukum, Fakultas Hukum UNISSULA, Semarang, e-mail: \\ sigitprihanto.59b@gmail.com \\ *** Dosen Fakultas Hukum UNISSULA
}

\begin{abstract}
Social life in everyday life often occurs between individual agreements with other individuals. The agreement between two or more individuals to perform an act to achieve a common goal is called an agreement. The covenant that is often used in everyday life is an agreement in oral form in the absence of a bond, so that if one party denies there is no legal sanction. People who want to make a written agreement can be made before a Notary. In making the agreement the parties freely express the intent and contents of the agreement before the Notary, but the problem is not all Notaries have the legal knowledge and ability enough to make the agreement in accordance with the wishes of the client. For that in the making of notarial agreement deed, there are things to note Notary, so that in making notariil deed can according to client wish without violating the rules that have been determined. The purpose of writing this journal is to know and analyze things that need to be noticed by Notary in making notarial agreement deed. The theory used is the theory of legal certainty associated with the notarization agreement deed made Notary can certainly not violate the rules that have been determined. The method used in the writing of this journal is literature method review books against books related to the theme of the journal that I created and also sourced from several journals from the internet. In making a notarial agreement deed, a notary must pay attention to matters in making the agreement, for which the Notary must use the precautionary principle in the making of Notariil agreement deed.
\end{abstract}

Keywords: Agreement, Notarial Agreement, Notary

\section{ABSTRAK}

Kehidupan bermasyarakat dalam sehari-hari sering kali terjadi kesepakatan antara individu satu dengan individu lain. Kesepakatan yang terjadi antara dua individu atau lebih untuk melakukan suatu perbuatan demi mencapai tujuan bersama disebut perjanjian. Perjanjian yang seringkali digunakan dalam kehidupan sehari-hari adalah perjanjian dalam bentuk lisan tanpa adanya suatu ikatan, sehingga jika salah satu pihak mengingkari maka tidak ada sanksi hukum. Masyarakat yang ingin membuat perjanjian secara tertulis dapat dilakukan dihadapan Notaris. Dalam pembuatan perjanjian para pihak bebas mengutarakan maksud dan isi perjanjiannya dihadapan Notaris, namun permasalahannya tidak semua Notaris memiliki pengetahuan hukum dan kemampuan yang cukup untuk membuat perjanjian yang sesuai dengan keinginan klien. Untuk itu dalam pembuatan akta perjanjian notariil, ada hal-hal yang perlu diperhatikan Notaris, agar dalam pembuatan akta notariil dapat sesuai dengan keinginan klien tanpa melanggar aturan-aturan yang telah ditetapkan. Tujuan penulisan jurnal ini adalah untuk mengetahui dan menganalisa hal-hal yang perlu diperhatikan oleh Notaris dalam membuat akta perjanjian notrariil. Teori yang digunakan adalah teori kepastian hukum yang berkaitan dengan akta perjanjian notariil yang dibuat Notaris dapat dipastikan tidak melanggar aturan-aturan yang telah ditetapkan. Metode yang digunakan dalam penulisan jurnal ini adalah metode literatur kaji pustaka terhadap buku-buku yang berhubungan dengan tema jurnal yang saya buat dan juga bersumber dari beberapa jurnal dari internet. Dalam membuat akta perjanjian notariil, notaris perlu memperhatikan hal-hal dalam membuat perjanjian, untuk itu Notaris harus menggunakan prinsip kehati-hatian dalam pembuatan akta perjanjian Notariil.

Kata kunci: Perjanjian, Akta Perjanjian Notariil, Notaris

\section{PENDAHULUAN}

Pengertian perjanjian di dalam Buku III KUH Perdata diatur di dalam Pasal 1313 KUH Perdata, yang menyebutkan perjanjian adalah suatu perbuatan dengan mana satu orang atau lebih mengikatkan dirinya terhadap satu orang lain atau lebih.
Definisi tersebut oleh para Sarjana Hukum dianggap memiliki kelemahan karena disatu pihak kurang lengkap dan dipihak lainnya terlalu luas. Dianggap kurang lengkap karena hanya merumuskan perjanjian sepihak saja, padahal dalam kehidupan sehari-hari di samping perjanjian sepihak juga dapat dijumpai suatu perjanjian yang para pihaknya mempunyai hak dan kewajiban. Perjanjian inilah 
yang disebut dengan perjanjian timbal-balik. Perjanjian timbal-balik ini juga merupakan perjanjian yang seharusnya tercakup dalam batasan perjanjian dalam Pasal 1313 KUH Perdata tersebut. ${ }^{1}$

Setiap individu bebas untuk melakukan perjanjian dengan individu lain untuk tercapainya tujuan yang dikehendaki. Para pihak yang ingin membuat perjanjian bebas menentukan bentuk perjanjian, isi perjanjian dan syarat-syarat dalam perjanjian. Namun agar perjanjian tersebut sah dan dapat dijadikan alat bukti yang kuat, para pihak harus membuat perjanjian dihadapan Notaris agar akta perjanjian tersebut menjadi akta notariil. Dalam membuat akta perjanjian notariil, Notaris harus memperhatikan hal-hal yang tidak melanggar Peraturan Perundang-undangan, ketertiban umum, dan kesusilaan. Sebelum akta perjanjian notariil dibuat, Notaris harus memperhatikan syarat-syarat sahnya perjanjian menurut Pasal 1320 KUHPerdata yaitu :

1) Sepakat mereka yang mengikatkan dirinya ;

2) Cakap untuk membuat suatu perjanjian ;

3) Suatu hal tertentu dan ;

4) Suatu sebab yang halal.

Notaris harus memiliki pengetahuan yang luas mengenai perjanjian agar dapat membuat akta perjanjian dalam bentuk apapun bahkan yang belum ada contoh akta perjanjiannya. Dengan pengetahuan yang mendalam mengenai perjanjian, Notaris dapat menanyakan kepada klien mengenai :2

1) Ruang lingkup mengenai perjanjian yang akan dibuat;

2) Data-data apa saja yang ada yang dimiliki oleh klien (parapihak), demikian juga semua peraturan yang terkait dengan materi dan substansi perjanjian tersebut;

3) Semua data, peraturan, semua yang terkait dengan ruang lingkup perjanjian yang dimintakan untuk dibuat;

4) Hak-hak dan kewajiban-kewajiban apa saja yang minta dirumuskan dalam redaksi perjanjian.

Dalam pembuatan akta perjanjian notariil, Notaris perlu membangun struktur akta dan menyusun sebuah akta Notaris sesuai anatomi akta. Ada beberapa hal yang dapat dijadikan dasar untuk membangun struktur akta Notaris, antara lain : 3

1. Latar belakang yang akan diperjanjikan.

2. Identifikasi para pihak (subjek hukum).

3. Identifikasi objek yang akan diperjanjikan.

\footnotetext{
1 Purwahid Patrik, Dasar-dasarHukum Perikatan, Mandar Maju, Bandung, 1994, hlm.45

2 Mulyoto, 2012, Perjanjian; Tehnik Cara Membuat Dan Hukum Perjanjian Yang Harus Dikuasai, Cakrawala Media, Yogyakarta, Hal. xiv

${ }^{3}$ Ibid, Hal. 37-38
}

4. Membuat kerangka akta.

5. Merumuskan substansi akta.

- Kedudukan para pihak

- Batasan-batasan (yang boleh atau tidak diperbolehkan) menurut aturan hukum.

- Hal-hal yang dibatasi dalam pelaksanannya.

- Pilihan hukum dan pilihan pengadilan.

- Klausula penyelesaian sengketa.

- $\quad$ Kaitannya dengan akta yang lain (jika ada).

Dalam hal ini Notaris berperan untuk mengarahkan klien dalam pembuatan isi perjanjian agar tidak bertentangan dengan undang-undang, ketertiban umum, dan kesusilaan. Perjanjian harus didasarkan pada konsensus atau kesepakatan dari pihak-pihak yang membuat perjanjian.Dengan asas konsensualisme, perjanjian dikatakan telah lahir jika ada kata sepakat atau persesuaian kehendak diantara para pihak yang membuat perjanjian tersebut. $^{4}$

Tujuan dari penulisan jurnal ini untuk mengetahui dan menganalisa hal-hal yang perlu diperhatikan oleh Notaris dalam membuat akta perjanjian notrariil. Maka permasalahan yang dibahas dalam penulisan jurnal ini, yaitu Apa hal-hal yang perlu diperhatikan oleh Notaris dalam membuat akta perjanjian notrariil ?

Manfaat dari pembahasan masalah ini adalah untuk memberikan pengetahuan tentang akta perjanjian notariill kepada masyarakat. Manfaat bagi Notaris, agar dalam membuat akta perjanjian notariil tidak terjadi kesalahan dan melanggar Peraturanperaturan yang ada.

\section{PEMBAHASAN}

Berdasarkan hasil kajian pustaka yang diteliti maka dapat dikemukakan bahwa hal-hal yang perlu diperhatikan oleh Notaris dalam membuat akta perjanjian notrariil sangat berguna bagi Notaris agar dalam pembuatan akta perjanjian notariil tidak melanggar aturan-aturan yang ada. Seorang Notaris harus menguasai pengetahuan mengenai perjanjian dan teknik pembuatan akta sebagaimana diatur dalam Undang-undang Nomor 2 Tahun 2014 tentang Jabatan Notaris yang selanjutnya akan disebut UUJN.

Akta perjanjian notariil adalah merupakan bukti tertulis, dan otentik yang sewaktu-waktu dapat dipakai sebagai alat bukti yang kuat bahkan sempurna bagi pihak-pihak yang mengadakan

\footnotetext{
${ }^{4}$ Ridwan Khairandy, 2004, Itikad Baik dalam Kebebasan Berkontrak, Program Pasca Sarjana Fakultas Hukum Universitas Indonesia, Jakarta, Hal. 27
} 
perjanjian. ${ }^{5}$ Hakim harus mengaggap sebagai bukti yang sempurna yang tidak memerlukan bukti tambahan sepanjang ternyata tidak terbukti sebaliknya. ${ }^{6}$

Sebelum membuat akta perjanjian notariil, Notaris harus memperhatikan syarat sahnya perjanjian. Apakah para pihak sudah memenuhi syarat sahnya perjanjian atau belum memenuhi syarat sahnya perjanjian. Berikut ini adalah table yang memaparkan syarat sahnya perjanjian menurut KUHPerdata maupun diluar KUHPerdata.

TABEL 1.

Syarat sah perjanjian

\begin{tabular}{|c|c|}
\hline $\begin{array}{c}\text { Syarat sahnya } \\
\text { perjanjian menurut } \\
\text { KUHPerdata }\end{array}$ & $\begin{array}{c}\text { Syarat sahnya perjanjian } \\
\text { diluar KUHPerdata }\end{array}$ \\
\hline $\begin{array}{l}\text { 1. Sepakat mereka } \\
\text { yang mengikatkan } \\
\text { dirinva. }\end{array}$ & $\begin{array}{l}\text { jilakukan dengan } \\
\text { oaik; } \\
\text { idak }\end{array}$ \\
\hline $\begin{array}{ll}\text { 2.Cakap } & \text { untuk } \\
\text { membuat } & \text { suatu } \\
\text { perjanjian ; } & \end{array}$ & $\begin{array}{l}\text { bertentangan dengan } \\
\text { kebiasaan; } \\
\text { 3. Harus berdasar atas }\end{array}$ \\
\hline $\begin{array}{l}\text { 3. Suatu hal tertentu } \\
\text { dan; }\end{array}$ & $\begin{array}{l}\text { asas } \\
\text { kepatutan/kepantasan; }\end{array}$ \\
\hline $\begin{array}{l}\text { 4.Suatu sebab yang } \\
\text { halal. }\end{array}$ & $\begin{array}{l}\text { 4. Harus tidak } \\
\text { melanggar/tidak } \\
\text { bertentangan dengan } \\
\text { ketertiban umum.? }\end{array}$ \\
\hline
\end{tabular}

Mengenai kata sepakat ada beberapa teori yang dapat dipakai sebagai pedoman, yaitu: ${ }^{8}$

1) Teori kehendak

Teori ini menganggap bahwa pihak-pihak hanya terikat kepada hal-hal yang benar-benar dikehendakinya.

2) Teori pernyataan atau kepercayaan

Di sini para pihak terikat kepada hal-hal yang telah dinyatakan, dengan pengertian bahwa hal ini dari pihak lain terdapat anggapan dan kepercayaan bahwa pernyataan itu cocok dengan kehendak sejati dari pihak yang menyatakan. ${ }^{9}$

Dilihat dari syarat-syarat sahnya perjanjian ini, dibedakan bagian perjanjian, yaitu bagian inti (wanzenlijke oordee), subbagian inti disebut

\footnotetext{
5 Mulyoto, 2012, Perjanjian; Tehnik Cara Membuat Dan Hukum Perjanjian Yang Harus Dikuasai, Cakrawala Media, Yogyakarta, Hal. 1

${ }^{6}$ Ibid, Hal. 1-2

${ }^{7}$ Ibid, Hal. 34-35

8 Wirjono Prodjodikoro, Asas-asas Hukum Perjanjian, Mandar Maju, Bandung, 2000, hlm. 29

9 Purwahid Patrik, Dasar-dasarHukum Perikatan,
} hlm. 56-57 esensialia dan bagian yang bukan inti disebut naturalia dan aksidentialia. ${ }^{10}$

a. Esensialia

Bagian ini merupakan sifat yang harus ada di dalam perjanjian, sifat yang menentukan atau menyebabkan perjanjian itu tercipta (constructieve oordeel)

b. Naturalia

Bagian ini merupakan sifat bawaan (natuur) perjanjian sehingga secara diam-diam melekat pada perjanjian, seperti menjamin tidak ada cacat dari benda yang dijual ( vrijwaring)

b. Aksidentialia

Bagian ini merupakan sifat yang melekat pada perjanjian yang secara tegas diperjanjikan oleh para pihak.

Undang Hukum Perdata Pasal 1330 hanya menyebutkan siapa yang tidak cakap untuk membuat perikatan adalah:

1) orang-orang yang belum dewasa

2) mereka yang ditaruh di bawah pengampunan

3) orang-orang perempuan, dalam hal-hal yang telah ditetapkan oleh Undang-undang dan pada umumnya semua membuat persetujuanpersetujuan tersebut.

Notaris dalam membuat akta perjanjian notariil harus jujur, cermat, teliti, tidak memihak salah satu pihak dan memahami semua peraturan yang berhubungan dengan akta yang akan dibuatnya. Adapun larangan-larangan dalam membuat perjanjian bagi Notaris. Larangan bagi Notaris dalam membuat perjanjian: ${ }^{11}$

a. Notaris dilarang membuat akta perjanjian yang memihak kepada salah satu pihak.

b. Notaris dilarang membuat akta perjanjian yang bertentangan dengan akta yang dibuat sebelumnya.

c. Notaris dilarang membuat akta pencabutan perjanjian pemberian kuasa secara sepihak dimana akta pemberian kuasa tersebut telah ditanda tangani oleh kedua belah pihak (pemberi kuasa dan penerima kuasa).

d. Notaris dilarang memberitahukan isi (segala sesuatu mengenai akta yang dibuatnya) dan segala keterangan yang diperolehnya guna pembuatan akta.

e. Notaris dilarang untuk tidak membacakan isi akta kepada para pihak, kecuali para pihak sudah membacanya sendiri, mengerti dan menyetujui, hal demikian sebagaimana dinyatakan dalam

\footnotetext{
10 Mariam Darus Badrulzaman, 2005, eka Hukum Bisnis, Alumni, Bandung, hal. 25

11 Mulyoto, 2012, Perjanjian; Tehnik Cara Membuat Dan Hukum Perjanjian Yang Harus Dikuasai, Cakrawala Media, Yogyakarta, Hal. 17
} 
penutup akta dan tiap halaman diparaf oleh para pihak/para penghadap, para saksi dan Notaris sedangkan halaman terakhir ditanda tangani para pihak, para saksi dan Notaris.

f. Notaris dilarang membuat akta perjanjian yang bertentangan dengan UU, ketertiban umum dan/atau kesusilaan.

g. Notaris dilarang membuat akta simulasi (bohongan) lebih-lebih dalam hal untuk tujuan yang bertentangan dengan UU.

Notaris harus memperhatikan perwakilan dalam perjanjian. Perwakilan demi hukum tidak dibenarkan untuk disubtitusikan, lembaga perwakilan dalam hukum privat dibedakan menjadi 3 (tiga) yaitu: ${ }^{12}$

- Perwakilan menjadi kontraktual yaitu perwakilan karena adanya pemberian kuasa, diatur dalampasal 1792 sampai dengan 1819 KUHPerdata.

- Perwakilan organic, yaitu seseorang yang berkedudukan di salah satu organ badan hukum mewakili badan hukum tersebut.

- Perwakilan demi hukum, yaitu seseorang yang karena kedudukannya sebagai missal: dalam kedudukannya selaku orang tua mewakili anaknya yang masih dibawah umur atau suami dan istri salah satu meninggal dunia maka suami/istri yang hidup lebih lama (masih hidup), maka demi hukum menjadi wali dari anak kandungnya tersebut.

Dari ketentuan Pasal 108 ayat 2 Kitab UndangUndang Hukum Perdata tersebut dapat disimpulkan bahwa seorang perempuan yang bersuami, untuk mengadakan suatu perjanjian memerlukan bantuan atau izin (kuasa tertulis) dari suaminya. ${ }^{13}$

Untuk perjanjian soal-soal yang kecil yang dapat dimasukkan ke dalam keperluan rumah tangga, si istri itu telah dikuasakan oleh suaminya, dengan demikian si istri dimasukkan ke dalam golongan orang-orang yang tidak cakap untuk berbuat sesuatu perjanjian. Perbedaannya dengan seorang anak adalah bila seorang anak yang belum dewasa ia harus diwakili oleh orang tua atau wakilnya, sedangkan seorang istri harus dibantu oleh sang suaminya. Apabila seseorang dalam membuat suatu perjanjian sendiri, akan tetapi yang tampil ke depan adalah wakilnya. Tetapi seseorang dibantu, berarti ia bertindak sendiri, hanyalah ia didampingi oleh orang lain yang membantunya, bantuan tersebut dapat diganti dengan surat kuasa atau surat izin tertulis.

Dalam pembuatan akta perjanjian notariil agar diusahakan didalam pembuatannya mengandung

\footnotetext{
${ }^{12}$ Ibid, hal. 18

13 Subekti, Hukum Perjanjian, Intermasa, Jakarta,1990, hlm. 19
}

unsur kelengkapan, kebenaran, kejelasan dan keabsahan. Maksudnya adalah: ${ }^{14}$

- Mengandung unsur kejelasan artinya:

- Mulai dari judul akta harus mengandung/mencerminkan secara garis beadr substansi dari isi akta.

- Redaksi setiap pasal tidak boleh berwayuh arti atau mempunyai arti lebih dari satu arti/bisa ditafsirkan lain.

- Jangan berpindah ke pasal yang lain sebelum tuntas terkait redaksi pasal tersebut.

- Memuat secara detail segala sesuatu yang memang harus diatur dalam akta/perjanjian tersebut.

- Mengandung unsur kebenaran :

- Usahakan sepanjang dimungkinkan mengupayakan kebenaran material. Hal demikian bisa diupayakan dengan pemberian nasehat hukum kepada para penghadap terkait dengan akta yang akan dibuat dan dikemukakan akibat hukum dan sanksi dalam hal tidak mengemukakan atau menyampaikan segala sesuatu selain daripada yang sebenarnya.

Mengenai kebatalan dan pembatalan perikatanperikatan diatur dalam Buku III, Bagian kedelapan, Bab IV (Pasal 1446-Pasal 1456 KUHPerdata). Bagian ini hanya secara sumier mengatur sebagian dari kebatalan, khususnya perjanjian yang dilakukan oleh mereka yang tidak cakap, yaitu mereka yang dibawah umur, ditaruh dibawah curatele, serta cacat dalam kehendak. Cacat dalam kehendak terjadi karena adanya paksaan, kekeliruan, tipuan dan penyalahgunaan keadaan. ${ }^{15}$

Kebatalan suatu perjanjian dibedakan antara: ${ }^{16}$

1. Dapat dibatalkan, dalam hal tidak dipenuhinya syarat subyektif yaitu :

- Tidak adanya kata sepakat, dan

- Tidak adanya kecakapan bertindak dan pihak-pihak yang membuat perjanjian.

2. Batal demi hukum, dalam hal tidak dipenuhinya syarat obyektif, yaitu:

- Tidak ada causa/obyek perjanjian

- Tidak mengandung causa yang dibenarkan menurut hukum.

3. Batal demi hukum karena Non existent, yaitu disebabkan karena:

- Tiadanya sesuatu yang esensi/pokok dalam perjanjian tersebut.

${ }^{14}$ Ibid, hal. 26

15 Habib Adjie, 2011, Kebatalan dan Pembatalan Akta Notaris, PT. Refika Aditama, Bandung, Hal. 4

16 Mulyoto, 2012, Perjanjian; Tehnik Cara Membuat Dan Hukum Perjanjian Yang Harus Dikuasai, Cakrawala Media, Yogyakarta, Hal. 44-45 
- Tiada dipenuhinya syarat yang diharuskan oleh UU sebagai contoh: PT,Yayasan didirikan tidak dengan akta Notaris (tidak notariil).

- Perjanjian fidusia dibuat hanya secara dibawah tangan (tidak notariil)

- Pendirian CV tidak ada Persero Komanditernya.

Notaris harus jujur, mandiri, cermat, dan tidak memihak, serta harus mengikuti semua peraturan tidak terbatas peraturan jabatan Notaris tetapi juga semua peraturan yang ada hubungannya dengan akta yang akan dibuat. ${ }^{17}$

Dalam menyusun kontrak bisnis agar dalam penyusunan kontrak dari segi legal benar-benar aman dan kuat, diusahakan menyusun kontrak sedetail mungkin agar dikemudian hari jika timbul sengketa dapat ditekan sekecil mungkin bahkan dihindari.

\section{SIMPULAN}

Berdasarkan pembahasan yang diangkat dalam jurnal ini, dapat diambil kesimpulan bahwa Dalam membuat akta perjanjian notariil, notaris perlu memperhatikan hal-hal dalam membuat perjanjian, untuk itu Notaris harus menggunakan prinsip kehatihatian dalam pembuatan akta perjanjian Notariil. Notaris dalam membuat akta perjanjian notariil dapat meminimalisir kesalaha kedepannya dengan cara memperhatikan hal-hal yang penting dalam pembuatan akta notariil. Notaris harus memiliki pengetahuan yang luas mengenai perjanjian agar dapat membuat akta perjanjian dalam bentuk apapun.

\section{DAFTAR PUSTAKA}

Habib Adjie, 2011, Kebatalan dan Pembatalan Akta Notaris, PT. Refika Aditama, Bandung, Hal. 4

Mulyoto, 2012, Perjanjian; Tehnik Cara Membuat Dan Hukum Perjanjian Yang Harus Dikuasai, Cakrawala Media, Yogyakarta

Mariam Darus Badrulzaman, Aneka Hukum Bisnis, Alumni, Bandung, 2005

Purwahid Patrik, Dasar-dasarHukum Perikatan, Mandar Maju, Bandung, 1994

Ridwan Khairandy, 2004, Itikad Baik dalam Kebebasan Berkontrak, Program Pasca Sarjana Fakultas Hukum Universitas Indonesia, Jakarta

Subekti, Hukum Perjanjian, Intermasa, Jakarta, 1990

${ }^{17}$ Ibid, hal. 27 